\title{
KEBIJAKAN HUKUM PIDANA DALAM MENANGGULANGI
} TINDAK PIDANA PERDAGANGAN BAYI

\author{
Oleh \\ Herlina *
}

\begin{abstract}
ABSTRAK
Kajian ini ditujukan untuk mengetahui kebijakan penanggulangan tindak pidana perdagangan bayi dalam hukum pidana pada saat ini dan prospek kebijakan di masa mendatang. Kebijakan penanggulangan tindak pidana perdagangan bayi dalam KUHP yang berlaku saat ini tidak mengenal tindak pidana perdagangan bayi. KUHP hanya mengatur perdagangan perempuan dan anak laki-laki yang belum cukup umur dimana tujuannya berbeda dengan tujuan perdagangan bayi. Demikian pula korporasi dalam KUHP tidak diakui sebagai subjek hukum sehingga hal ini menyulitkan dalam pertanggungjawaban pidananya. Dalam UndangUndang Perlindungan Anak tidak secara tegas mengatur tentang perdagangan bayi namun secara implisit telah dapat mengakomodir tindak pidana perdagangan bayi, Tetapi Undangundang tersebut tidak menjelaskan secara rinci perbuatanperbuatan apa saja yang sudah dapat dikategorikan sebagai perbuatan tindak pidana perdagangan anak termasuk bayi. Kebijakan penanggulangan tindak pidana perdagangan bayi dalam hukum pidana dimasa mendatang, baik itu dalam Konsep KUHP 2004 maupun dalam RUU Pemberantasan Perdagangan Perempuan Dan Anak belum ada pasal yang khusus mengatur perdagangan bayi, oleh sebab itu perlu dikaji kembali dan perlu adanya perbandingan dengan negara lain untuk mencapai hasil yang maksimal.
\end{abstract} Kata Kunci : Kebijakan Hukum Pidana, Tindak Pidana,

\section{A. LATAR BELAKANG}

Tindak pidana perdagangan bayi yang akhir-akhir ini sering terjadi dan telah menjadi sorotan masyarakat karena bukan saja

Herlina, SH.MHum adalah Alumni PMIH UNDIP sudah menjadi isu nasional tetapi sudah menjadi isu internasional. Perdagangan manusia/bayi (trafficking) termasuk kejahatan terhadap kemanusian dan merupakan pelanggaran yang serius terhadap Hak Asasi Manusia (HAM) karena tidak hanya merusak nilai-nilai hak asasi 
manusia tetapi juga telah merendahkan derajat manusia, dimana manusia disini disamakan dengan barang atau benda.

Penanganan kasus tindak pidana perdagangan bayi, harus dilakukan secara komprehensif. Karena kasus perdagangan bayi telah melibatkan pihak luar negeri. Dengan pertimbangan bahwa perdagangan bayi telah dilakukan secara terorganisasi serta melihat sulitnya pengungkapan kasusnya, oleh sebab itu, aparat Kepolisian diharapkan bukan hanya sekedar menuntaskan kasus per kasus, akan tetapi, Polisi harus berupaya mencari alkernatif lain, agar penanganan kasus perdagangan bayi mencakup penyelesaian menyeluruh secara transnasional. Dan dari segi kebijakan Indonesia juga belum mampu untuk menanggulangi masalah tindak pidana perdagangan bayi ini secara serius dan tuntas.

Peraturan yang diberlakukan dalam menanggulangi tindak pidana perdagangan bayi pada saat ini selain KUHP adalah UU No. 23 Tahun 2002 tentang Perlindungan Anak. Dalam KUHP Indonesia hanya ada satu pasal yang terkait dengan persoalan perdagangan perempuan dan anak, yaitu Pasal 297. Sedangkan dalam UU No. 23 Tahun 2002 masalah perdagangan anak/bayi diatur Pasal 83.
B. PERMASALAHAN.

1. Bagaimana kebijakan penanggulangan tindak pidana perdagangan bayi dalam hukum pidana pada saat ini

2. Bagaimana sebaiknya kebijakan penanggulangan tindak pidana perdagangan bayi dalam hukum pidana dimasa "mendatang.

\section{KERANGKA TEORI}

Sebagai generasi penerus bangsa, seorang bayi harus ditempatkan pada posisi yang aman sebagaimana yang ditegaskan pada akhir Deklarasi PBB tanggal 20 November 1959 tentang Hak-Hak Anak bahwa anak-anak harus dibesarkan dalam semangat/jiwa yang penuh pengertian, toleransi, persahabatan antar bangsa, perdamaian dan persaudaraan yang bersifat universal

Pada umumnya manusia tidak akan puas dengan apa yang dialaminya, sehingga berbagai usaha dilakukan untuk memenuhi kepuasan tersebut. Dalam hal pemilikan anak, salah satu usaha yang dilakukan adalah mengangkat anak atau adopsi. Menurut Surojo Wignjodipuro Adopsi (mengangkat anak) adalah suatu perbuatan pengambilan anak orang lain ke dalam keluarga sendiri sedemikian rupa, sehingga antara orang yang memungut anak dan yang memungut itu timbul suatu 
hukum kekeluargaan yang sama, seperti yang ada antara orang tua dengan anak kandungnya sendiri ${ }^{56}$. $\mathrm{Hal}$ ini sesuai dengan syarat dalam pengangkatan anak yang di atur dalam Pasal 39 UU No.23 Tahun 2002 tentang Perlindungan Anak.

Dalam perkembangan sekarang menurut pengamatan para ahli, seperti yang ditulis oleh Kustiniyati Mochtar 57, bahwa adopsi antar negara mulai dilakukan setelah perang dunia kedua. Ketika itu mulai tampak keinginan orang dari negara maju untuk mengangkat anak dari negara miskin, yang mereka sebut dari dunia ketiga. Alasannya tak lain adalah rasa sosial dan kemanusiaan, keinginan memberi bantuan kepada yang lebih miskin dan adanya fakta, bahwa banyak orang di negara maju tak dapat mempunyai anak sendiri. Sejak itu jumlahnya terus meningkat, sehingga mencapai jumlah sebagaimana sekarang ini.

Dari uraian di atas, maka jelaslah bahwa masalah pengangkatan anak ini, walaupun pada dasarnya hanyalah masalah keluarga, namun akhirnya menjelma menjadi problema masyarakat, bahkan hubungan antar negara yang sudah barang tentu akan mengarah pula kepada soal-soal politik,

\footnotetext{
56 Muderis Zaini, Adopsi Suatu Tinjauan dari Tiga Sistem Hukum (Jakarta : Sinar Grafika, 2002), hal 5

Ibid, hal 13
}

hukum/kejahatan dan lain sebagainya.

Kejahatan perdagangan manusia bukan hanya merusak nilai-nilai asas manusia, tetapi telah merendahkan derajat manusia. Pemerintah yang mentolerir perdagangan manusia sama saja mentoleransi perbudakan. $^{58}$

- Karena masalah moralitas yang melekat pada seorang manusia juga tidak kalahnya memegang peranan penting dalam terjadinya tindak pidana perdagangan bayi. Oleh sebab itu menurut Barda Nawawi Arief 59 "Hukum pidanalah yang paling dekat dan paling sarat dengan nilai-nilai kejiwaan/moralitas" . Dan dalam rangka pembaharuan hukum pidana yang dimaksud menciptakan hukum positif secara nasional; tidak bisa dilepaskan dari nilai-nilai yang timbul dan berkembang dalam masyarakat, hukum yang hidup dalam masyarakat karena masyarakat memegang teguh nilai-nilai kemasyarakatn sebagai pedoman untuk berbuat dan tidak berbuat.

Berkaitan dengan kebijakan hukum pidana, Barda Nawawi Arief mengemukakan bahwa istilah "politik hukum pidana" dalam kepustakaan

\footnotetext{
58 Manusia Mempordagangkan Manusia Kojahatan 39 Kemananusiaan, Kompas 8 Maret, 2004 Barda Nawawi Arief, Beberapo Aspok Pengembangn IImu Hukum Pidano (Menyongsong Generasi Baru Hukum Pidana Indonesia), Pidato Pengukuhan Guru Besar Fakultas Hukum Undip (Semarang : 1994), hal 28
} 
asing, istilah "politik hukum pidana juga dikenal dengn berbagai istilah lain, diantaranya adalah "penal policy", "criminal law policy", atau "strafrechtpolitiek".

Selanjutnya Barda Nawawi Arief mengemukakan sebagai berikut :

Usaha penanggulangan kejahatan lewat pembuatan undang-undang (hukum) pidana pada hakekatnya juga merupakan bagian integral dari usaha perlindungan masyarakat (social defence) dan usaha mencapai kesejahteraan masyarakat (social welfare). Oleh karena itu wajar pulalah apabila kebijakan atau politik hukum pidana juga merupakan bagian integral dari kebijakan atau politik sosial (social policy). Kebijakan sosial (social poicy) dapat diartikan sebagai segala usaha yang rasional untuk mencapai kesejahteraan masyarakat dan sekaligus mencakup perlindungan masyarakat. Jadi di dalam pengertian "social policy" sekaligus tercakup di dalamnya "social welfare policy" dan "social defence policy"

Penggunaan hukum pidana sebagai suatu upaya untuk mengatasi masalah sosial (kejahatan) termasuk dalam bidang penegakan hukum (khususnya penegakan hukum pidana). Oleh karena itu sering dikatakan bahwa politik atau

${ }^{60}$ Barda Nawawi Arief, Op Cit, hal 24 kebijakan hukum pidana merupakan bagian dari penegakan hukum (law enforcement policy ${ }^{61}$

\section{HASIL PENELITIAN DAN PEMBAHASAN}

Bertolak dari
$\begin{aligned} & \text { kebijakan } \\ & \text { (mencakup }\end{aligned}$ kendekatan
sosial, kebijakan kriminal dan
kebijakan penegakan hukum yang
berkaitan secara integral), maka
faktor-faktor yang harus di-
pertimbangkan dalam menentukan
perbuatan perdagangan bayi sebagai
tindak pidana adalah :

1) Seorang anak (bayi) merupakan aset pembangunan nasional yang sangat besar artinya. Masa depan bangsa terletak ditangan generasi generasi penerus yang bermula dari bayi. Oleh sebab itu perhatian dan pertindungan terhadap seorang anak (bayi) serta kualitas kehidupan adalah sangat penting demi kemajuan bangsa dan negara.

2) Berkaitan dengan butir (1), perbuatan memperdagangkan bayi harus ditempatkan pada keadaan yang sangat membahayakan, tidak berperikemanusiaan dan perbuatan yang benar-benar tidak dikehendaki, sangat dibenci dan merugikan atau yang dapat

${ }^{61}$ Barda Nawawi Arief, Bunga Rampai Kebijakan Hukum Pidana, (Bandung : Citra Aditya Bakti, 2002), hal 26 
mendatangkan koban. Selain itu harus pula dipertimbangkan sejauhmana perbuatan memperdagangkan manusia (bayi) itu telah bertentangan bahkan merusak nilai-nilai fundamental kemanusiaan dalam masyarakat.

3) Perlu diperhitungkan apakah biaya yang harus dikeluarkan (cost) dalam pembuatan suatu undang-undang. Tetapi dalam hal tindak perdagangan manusia (bayi) menurut penulis pertimbangan tentang biaya (cost) bukan merupakan pertimbangan yang penting hal ini disebabkan karena menyangkut harkat dan martabat manusia yang seharusnya dijunjung tinggi.

4) Selanjutnya perlu juga dipertimbangkan kapasitas atau kemampuan daya kerja dari badan-badan penegak hukum di Indonesia dalam menegakkan ketentuan-ketentuan yang mengatur delik perdagangan manusia (bayi). Karena masalah perdagangan manusia (bayi) ini sudah berskala kejahatan transnasional bahkan internasional. Maka harus diprediksi bagaimana kondisi personil aparat penegak hukum baik secara kuantitas maupun kualitas, misalnya menyangkut tingkat pendidikan, tingkat profesionalisme, pengalamannya serta bagaimana penyebarannya di Indo- nesia. Selain itu harus pula ditinjau bagaimana kondisi-kondisi yang menyangkut pelaksanaan tugasnya atau cara kerjanya, misalnya, menyangkut sistem hukum negara lain, prosedurnya maupun birokrasinya.

5) Akhirnya perlu pula dikaji akibat sosial dari pengkriminalisasian atau pendekriminalisasian dari kejahatan perdagangan manusia (bayi). Misalnya bagaimana kemungkinan pengaruh dari kriminalisasi dan dekriminalisasi terhadap kejahatan perdagangan manusia (bayi) bagi prilaku atau sikap pelaku pada khususnya dan masyarakat pada umumnya.

Harus disadari, upaya penghapusan perdagangan bayi tidak hanya berdasar pada instrumen legal tetapi juga harus mampu merubah budaya masyarakat yang permisif terhadap praktek perdagangan bayi.

Kebijakan hukum pidana dalam perdagangan bayi di Indonesia saat ini menggunakan Kitab UndangUndang Hukum Pidana dan UndangUndang Nomor 23 Tahun 2002 Tentang Perlindungan Anak.

Tidak ada satu pasalpun dalam KUHP yang mengatur tentang perdagangan bayi. Sebagai solusi untuk menindak pelaku menurut hukum maka penegak hukum menerapkan Pasal 297 KUHP. 
Sedangkan pasal-pasal lain yang ada hubungannya dengan perdagangan bayi juga diterapkan ialah Pasal 277, 328 Pasal 330, 378 KUHP. Adapun bunyi dari Pasal 297 adalah, " Perdagangan wanita dan perdagangan anak lakilaki yang belum cukup umur, diancam dengan pidana penjara paling lama enam tahun".

Pasal ini digunakan untuk menangkap pelaku perdagangan anak perempuan dan anak laki-laki yang belum cukup umur. Terhadap pasal tersebut maka menurut R.Soesilo "perbuatan yang dilarang adalah perbuatan-perbuatan yang dilakukan dengan maksud untuk menyerahkan perempuan guna pelacuran. Apabila rumusan Pasal 297 ini dikaitkan dengan tindak pidana perdagangan bayi maka dapat diidentifikasikan hal-hal sebagai berikut :

a. tidak menyebutkan secara jelas tentang perbuatan-perbuatan atau rangkaian perbuatan yang sudah dapat dikategorikan sebagai perbuatan memperdagangkan atau memperniagakan bayi.

b. Tidak ada penegasan tentang usia anak yang dapat dimasukkan dalam kategori bayi.

c. Dilihat dari tujuannya, Pasal 297 hanya mengatur perdagangan dengan tujuán untuk dilacurkan, tidak untuk tujuan adopsi. d. Pasal 297 tidak menyentuh sama sekali perihal kemungkinan bayi yang diserahkan oleh orang tua masing-masing kepada seseorang dengan tujuan untuk menjualnya kembali atau menyerahkan kepada orang-orang asing untuk dibawa ke negaranegara masing-masing sebagai "anak angkat" akan tetapi oleh "orang tua angkat mereka" mereka itu kemudian telah dimanfaatkan untuk berbagai tujuan, misalnya untuk memenuhi kebutuhan akan organ-organ tubuh (transplantasi) atau perbuatan kejahatan lain yang bertentangan dengan hak-hak anak yang telah diakui masyarakat dunia.

e. Tidak mengatur larangan dan ancamanan yang ditujukan kepada mereka yang telah menerima bayi untuk diangkat dengan cara yang tidak sesuai dengan yang diinginkan oleh Pemerintah Indonesia, sehingga menurut P.A.F.Lamintang ${ }^{62}$ "memadai kiranya jika ketentuan pidana yang melarang perbuatan-perbuatan seperti yang dimaksudkan di atas dirumuskan sebagai berikut :
1. Barang siapa dengan sengaja menyerahkan se- orang anak yang belum dewasa kepada seseorang

\footnotetext{
${ }^{62}$ Ibid, hal 245
} 
warga negara asing untuk diangkat sebagai anak, dengan alasan atau dengan sebutan apapun, secara bertentangan dengan kemauan anak itu sendiri dan dilakukan tanpa adanya ijin dari ketua Pengadilan Negeri di tempat tinggalnya

2. barang siapa dengan sengaja menerima penyerahan seorang anak yang belum dewasa dari orang tuanya, walinya atau dari orang yang mendapat kepercayaan : untuk mengurus, memelihara atau menjaga ' anak 'tersebut secara bertentangan dengan kemauan anak itu sendiri atau tanpa mendapat ijin dari Ketua Pengadilan Negeri ditempat tinggal orang yang menyerahkan anak tersebut, dengan maksud untuk membawanya keluar dari Indonesia.

Sampai saat ini, masih sering ditemukan fakta para pelaku tindak pidana perdagangan bayi ternyata dijatuhkan pidana tidak setimpal dengan jenis dan akibat dari kejahatan tersebut. Hal ini disebabkan belum adanya kesamaan pandangan mengenai perbuatan yang dilakukan oleh pelakku dengan pasal-pasal yang terdapat dalam peraturan perundang-undangan yang berlaku. Memberlakukan Pasal 277 dan 330 KUHP, dalam menyelesaikan kasus perdagangan bayi di Indonesia belum mengakomodir sepenuhnya karena perundangundangan yang ada tidak mengatur secara jelas mengenai tindak pidana perdagangan bayi.

- Pasal 83 UU. NO.23 Tahun 2002 digunakan untuk menjerat pelaku yang melakukan perbuatan memperdagangkan, atau menculik anak termasuk bayi. Setiap orang dalam undang-undang ini adalah termasuk juga korporasi.

Selain dari Pasal 83 di atas, ada beberapa pasal yang terkait dengan masalah perdagangan bayi. Pasal tersebut adalah :

Pasal 78, dapat dikenakan pada pelaku yang mengetahui dan membiarkan terjadinya tindak pidana perdagangan anak atau bayi

Pasal 79 digunakan untuk menghukum pelaku yang melakukan pengangkatan anak tetapi tidak untuk kepentingan terbaik bagi anak yang diangkatnya serta tidak berdasarkan ketentuan yang berlaku sebagaimana ditentukan dalam Pasal 39 (ayat 1). Pasal ini juga akan menghukum pelaku. yang memutuskan hubungan darah antara anak yang diangkat dengan orang tuanya secara melawan hukum Pasal 39 ayat (2) sedangkan ayat (4) digunakan untuk menghukum 
pelaku yang sengaja menyerahkan hak pengasuhan anak kepada warga negara asing bukan sebagai upaya terakhir.

Pasal 84 dapat dikaitkan dengan tindak pidana perdagangan bayi karena kemungkinan bisa terjadi bahwa bayi-bayi tersebut sengaja dibeli dengan tujuan untuk diambil organ-organ tubuhnya (transplantasi)

Pasal 85 dapat menjerat pelaku yang melakukan jual beli organ tubuh/jaringan bayi, atau melakukan pengambilan organ tubuh/atau jaringan tubuh bayi, dimana anak/bayi yang menjadi korban tersebut didapat dari kegiatan perdagangan bayi.

Tidak ada rumusan yang khusus tentang tindak pidana perdagangan bayi dalam Konsep KUHP Tahun 2004. Konsep hanya mengatur tentang perdagangan orang, yang sudah barang tentu disini termasuklah seorang bayi. Tindak Pidana Perdagangan Orang dirumuskan dalam Pasal 526. Sedangkan pasal-pasal lain yang ada kaitannya dengan perdagangan bayi adalah adalah Pasal 528, Pasal 529, Pasal 530, Pasal 531, Pasal 533, Pasal 534, Pasal 535, Pasal 539, Pasal 540, Pasal 541.

Rumusan tindak pidana perdagangan orang/ bayi terdapat dalam Pasal 526 yang akan menjerat siapa saja, dari orang tua bayi itu sendiri, wali, orang lain yang berwewenang atas bayi dan para pelaku yang melakukan perbuatan-perbuatan serta cara-cara seperti yang disebutkan dalam pasal tersebut.

Dalam tindak pidana perdagangan orang, pelaku tidak selalu sama, artinya mulai dari tahap perekrutan" sampai jatuhnya bayi ketangan pembeli selalu dilakukan oleh orang yang berbeda. Dengan demikian rangkaian perbuatan dalam pasal merupakan perbuatan yang berdiri sendiri sehingga pelakunya masing-masing dapat dikenakan sanksi pidana sebagai pelaku utama. Dikaitkan dengan tindak pidana perdagangan bayi, rumusan Pasal 526 dirasakan kurang lengkap, karena belum sama sekali menyentuh para adoptan yang dengan sengaja atau tanpa menghiraukan apakah bayi yang yang akan diadopsinya tersebut merupakan bayi korban perdagangan.

Demikian juga halnya dengan tujuan dari perumusan di atas apabila dikaitkan dengan tindak pidana perdagangan bayi dirasakan kurang tepat, hal ini disebabkan karena bayi yang diperjual belikan tersebut umumnya adalah untuk dipelihara atau dijadikan anak angkat, walaupun hal ini tidak menutup kemungkinan dipergunakannya bayi tersebut untuk halhal lain yang juga membahayakan kelangsungan hidupnya. Selain itu 
orang yang menampung bayi untuk sementara sebelum dijual tidak tertampung dalam rumusan Pasal 526.

Rumusan Pasal 529 terdapat pemberatan ancaman pidana karena mengakibatkan korban (bayi) mengalami luka berat, tertular penyakit yang membahayakan jiwa, sampai pada matinya korban atau bayi. Bagian dari rumusan pasal di atas yang mengatakan "kehilangan fungsi produksinya" merupakan rumusan yang tidak dapat diterapkan untuk tindak pidana perdagangan bayi

Tindak pidana perdagangan orang/bayi merupakan salah satu kejahatan yang terorganisir maka sudah sewajamya apabila dalam merumuskan ancaman pidananya akan diperberat karena dengan terorganisimya perbuatan-perbuatan tersebut, maka akan semakin rapi cara kerjanya dan semakin sulit untuk diungkap sehingga semakin banyak bayi-bayi atau para orang tua bayi yang akan menjadi korban tindak pidana perdagangan bayi.

Membuat palsu atau memalsukan dokumen negara atau dokumen lain atau membuat palsu atau memalsukan identitas dalam dokumen negara atau dokumen lain merupakan perbuatan yang sering dilakukan dalam tindak pidana perdagangan bayi dan perbuatan ini dapat merupakan rangkaian perbuatan tindak pidana perdagangan bayi yang terorganisir yang sasaran pembelinya adalah warga negara asing yang biasanya teliti terhadap prosedur hukum. Pelaku dalam tindak pidana ini dinyatakan dalam Pasal 533 adalah "setiap orang" dan apakah setiap orang disini termasuk pejabat negara seperti hakim. Karena banyak kasus yang terjadi bahwa mudahnya warga negara asing mengadopsi bayi Indonesia disebabkan mudahnya para hakim meloloskan permintaan adopsi dimana kebenaran dokumen yang diajukan belum tentu kebenarannya.

Berdasarkan rumusan Pasal 539 diketahui bahwa bantuan, kemudahan, sarana dan keterangan yang diberikan tersebut dilakukan sebelum terjadinya tindak pidana. Dalam pasal perlu dijelaskan tentang bantuan, kemudahan dalam bentuk apa yang diberikan sehingga lebih jelas arahnya.

Pasal-pasal yang mengatur tentang Tindak Pidana Perdagangan Orang/Bayi dalam Konsep KUHP merumuskan kesalahan dalam arti semua tindak pidana yang dilakukan merupakan kesengajaan dan bukan karena kealpaan. Setiap orang" dalam pengertian Konsep dapat berarti individu atau dapat juga berarti korporasi. Tindak pidana perdagangan bayi pelakunya selain perseorangan tetapi juga korporasi (sindikat) yang mana dalam hal ini pertanggungjawaban pidana bagi pelaku yang bekerja sama dalam 
korporasi adalah masing-masig sebagai pelaku utama sehingga ancaman hukumannya adalah diperberat yaitu ditambah $1 / 3$ dari ancaman pelaku utama.

Dalam tindak pidana perdagangan orang/bayi, pidana yang diancamkan adalah :

- Sekaligus dua pidana pokok;

- menjatuhkan pidana pokok saja; Dalam Rancangan UU Pemberantasan Perdagangan Perempuan dan Anak (RUU PPPA), perumusan tindak pidana bayi dapat dikategorikan dalam tindak pidana perdagangan anak yaitu yang terdapat dalam Pasal 5, 8, 9 ayat (2), 10, 11, 12, 13, 14, 15. Sedangkan Pasal 16 dan 17 mengatur tindak pidana perdagangan perempuan dan anak/bayi yang dilakukan oleh korporasi.

Unsur-unsur perbuatan yang terdapat dalam Pasal 5 RUU PPPA tidak saja menjadikan bayi sebagai korban langsung, tetapi dapat juga menjadikan ibu-ibu bayi atau perempuan-perempuan hamil sebagai korban.

Berdasarkan rumusan Pasal 10 RUU PPPA maka kelengkapan dokumen dalam hal adopsi dapat menyebabkan tindak pidana perdagangan bayi menjadi lancar untuk dilakukan. Pihak yang berwenang dalam hal ini Pengadilan Negeri (hakim) yang mengeluarkan dokumen pengesahan adopsi yang tidak valid dapat diancam dalam pasal ini walaupun dilakukan karena kealpaan. Dengan demikian untuk yang akan datang unsur kealpaan hendaknya secara tegas dicantumkan dalam rumusan deliknya.

Bentuk pemaksaan tidak dijelaskan dalam rumusan delik Pasal 11, oleh sebab itu untuk yang akan datang hal ini perlu diperjelas sejauh mana perbuatan memaksa itu dapat menimbulkan terjadinya tindak pidana perdagangan bayi. Ancaman pidana dalam pasal ini disamakan dengan ancaman sebagai pelaku utama mengingat pelakunya adalah pejabat negara yang seharusnya bertindak sebagai pengayom dari hak-hak warganegaranya termasuk bayi.

Berdasarkan rumusan pasal-pasal dalam RUU PPPA mengenai tindak pidana perdagangan perempuan dan anak, belum semua pasal dapat diterapkan pada tindak pidana perdagangan bayi mengingat spesifik dari tindak pidana perdagangan bayi yang berlatar belakang adopsi namun dapat dapat dijadikan alat untuk melakukan kejahatan-kejahatan lain yang berbahaya bagi kelangsungan hidup bayi. Untuk masa mendatang perlu kiranya dipertimbangkan apakah suatu perbuatan sebagai tindak pidana perdagangan bayi apabila seorang ibu yang tengah mengandung membuat suatu pernyataan mengenai persetujuan untuk adopsi dengan 
pertimbangan ekonomi dan bagaimana apabila baik perseorangan atau korporasi atau lembaga yang sengaja merekrut wanita-wanita atau pasangan-pasangan yang akan melahirkan dengan tujuan memperdagangkan bayi-bayi yang akan dilahirkan.

Ancaman pidana berdasarkan rumusan pasal-pasal dalam RUU PPPA termasuk tinggi dan untuk yang akan datang dapat saja dijatuhkan ancaman lebih tinggi untuk delik-delik tertentu mengingat tindak pidana perdagangan bayi biasanya selalu dikuti atau sekaligus adanya tindak pidana lain seperti penipuan, tindak pidana memisahkan secara paksa bayi dan orang tuanya, tindak pidana menelantarkan bayi dan sebagainya.

Selanjutkan akan dikaji mengenai Kebijakan Hukum Pidana dalam penanggulangan perdagangan sebagai Kajian Perbandingan.

\section{Tindak Pidana Perdagangan Bayi Dalam KUHP Korea.}

Pasal yang mengatur perdagangan anak atau bayi adalah Pasal 287, Pasal 289 dan Pasal 290. Dilihat dari jenis pidananya (straf sort) baik KUHP Korea maupun KUHP Indonesia samasama menjatuhkan sanksi pidana penjara. Sedangkan dilihat dari lamanya pidana (straf maat) sanksi pidana dalam KUHP Korea lebih berat yaitu dipidana paling lama sepuluh tahun penjara dibandingkan sanksi dalam KUHP Indonesia yaitu paling lama tujuh tahun penjara dan menjadi paling lama sembilan tahun apabila penculikan/melarikan anak belum berumur dua belas tahun dan dilakukan dengan tipu muslihat, kekerasan, atau dengan ancaman kekerasan, dimana hal ini tidak di atur dalam KUHP korea.

Rumusan pasal 289 tentang tindak pidana penculikan, juga menyangkut tindak pidana perdagangan orang yang korbannya bisa anak-anak dan orang dewasa, dimana tindak pidana dilakukan dengan maksud untuk diangkut keluar dari Republik Korea. Apabila perbuatan-perbuatan tersebut dilakukan sebagai kebiasaan atau sebagai mata pencaharian, maka sanksi pidananya diperberat. Dengan domikian , dalam mengantisipasi terjadinya tindak pidana perdagangan orang KUHP Korea lebih maju dibandingkan KUHP Indonesia.

Jenis sanksi yang diterapkan dalam tindak pidana perdagangan bayi adalah pidana pokok berupa perampasan kemerdekaan (penjara) dan tidak ada pidana tambahan, walaupun dalam KUHP Korea juga mengatur pidana tambahan yang terdapat dalam Pasal 49 dengan judul "Perampasan Bersifat sebagai Tambahan" yang isinya menyebutkan, bahwa : "Perampasan akan dikenakan sebagai tambahan pada 
pidana yang lain. Walaupun suatu putusan pemidanaan tidak diberikan kepada seorang pelaku, perampasan dapat diperintahkan jika persyaratannya terpenuhi". Sistem perumusan sanksi dan pemidanaan dalam pasal-pasal yang terkait tindak pidana perdagangan bayi dalam KUHP Korea menganut sistem tunggal.

\section{Tindak Pidana Perdagangan Bayi Dalam KUHP Prancis}

Dalam Code Penal tidak diatur tentang perdagangan bayi, tetapi perlindungan terhadap anak atau bayi untuk tidak dipisahkan dari orang tua atau dari orang yang berhak memeliharanya diatur dapat ditemukan pada Bagian VI, Paragraf I (Kejahatan berat dan kejahatan ringan terhadap seorang anak) Pasal 351 - 1 dan Paragraf 2 (Penculikan orang yang belum dewasa), Pasal 354

Rumusan Pasal 351 di atas menyerupai rumusan Pasal 330 KUHP Indonesia yang mengatur tentang penculikan. Rumusan tersebut juga lebih luas cakupannya karena selain perbuatan penculikan juga ditambah dengan perbuatan dipindahkan, disingkirkan.

Ancaman pidana yang dirumuskan Pasal 354 adalah kurungan tersendiri (penjara) yang menurut Pasal 12 dari undang- undang ini adalah berkisar anatra 5 (lima) sampai 10 (sepuluh) tahun yang berarti ada batas minimum dan batas maksimum, dimana hal ini berbeda dengan Pasal 330 KUHP Indonesia mencatumkan batas maksimum yaitu 7 (tujuh) tahun dan diperberat menjadi maksimum 9 (sembilan) tahun bila tindak pidana dilakukan dengan tipu muslihat dan terhadap anak yang belum berumur dua belas tahun, sedangkan anak yang belum dewasa menurut Code Penal adalah anak yang belum berumur 13 tahun.

Tidak ada satu pasal pun dalam Code Penal (KUHP Perancis) yang mengatur tindak pidana perdagangan orang, baik itu mengenai perempuan anak atau bayi. Dimungkinkan pengaturan semacam itu khususnya tindak pidana perdagangan bayi tidak diperlukan dinegaranya yang kategori negara maju. Fakta menunjukkan bahwa para adoptan itu berasal dari negara-negara yang tingkat ekonomi dan kesadaran akan penghargaan terhadap hak-hak manusia lebih tinggi, walaupun tidak menutup kemungkinan mengadopsi bayi karena ada tujuan tertentu yang mengakibatkan seorang bayi kehilangan hak-haknya. 


\section{Tindak Pidana Perdagangan Bayi di Pilipina.}

Untuk mengantisipasi adanya tindak perdagangan bayi, negara Pilipina dapat dikatakan lebih maju dibanding Indonesia. Hal ini dapat dilihat dari apa yang di atur dalam Republic Act No. 760 (child trafficking). Ruang Lingkup perdagangan bayi terdapat dalam Pasal 4 ayat (8) Republik Act No.760, yaitu ${ }^{63}$ Rumusan tindak pidana perdagangan dinegara Pilipina telah mengatur secara luas dan rinci, karena dengan tindakan membuat persetujuan untuk menyerahkan anak yang akan dilahirkan dengan alasan ekonomi, seorang ibu sudah dikategorikan melakukan tindak pidana perdagangan bayi, padahal bayi dan tindak pidana tersebut belum tentu terlaksana.

Para pelaku yang dapat dipertanggungjawabkan dalam tindak pidana perdagangan bayi, juga disebutkan secara tegas yaitu meliputi ibu kandung, kedua orang tua, orang lain, dokter maupun lembaga (badan hukum). Rumusan sebagaimana dalam Pasal 4 ayat (8) Republik Act No.760 tersebut tidak terdapat baik dalam KUHP, UU No.23 Tahun 2002, maupun dalam Konsep KUHP 2004., hal ini

${ }^{63}$ http/www DOJ com, (Web Site Departemen of Republik of the Philifines).Republic Act No.760 (Child Trafficking) menunjukkan bahwa Republik Act No. 760 telah mengakomodasi secara lebih baik atas respons perkembangan zaman, dibandingkan dengan peraturan-peraturan mengenai perdagangan bayi yang berlaku sekarang ini.

Rumusan tindak pidana perdagangan bayi juga terdapat daläm Pasal 4 ayat (7) Republik Act No.760 (child trafficking) yang mengandung dua pengertian tentang tindak pidana perdagangan bayi, yaitu mengatur adanya persetujuan yang sah dalam hal menjadikan anak dibawah pengawasan seorang wali. Rumusan tersebut belum diatur dalam KUHP Indonesia, sehingga perlu mendapat perhatian dalam merumuskan peraturan perundang-undangan yang akan datang.

\section{E. KESIMPULAN.}

Permasalahan pokok yang diangkat dalam penelitian ini adalah (1) mengenai kebijakan penanggulangan tindak pidana perdagangan bayi dalam hukum pidana pada saat ini dan (2) mengenai kebijakan penanggulangan tindak pidana perdagangan bayi dalam hukum pidana dimasa mendatang.

Dari pembahasan kedua pokok permasalahan di atas, dapat ditarik kesimpulan sebagai berikut : 
1. Mengenai kebijakan penanggulangan tindak pidana perdagangan bayi dalam hukum pidana pada saat ini adalah :

a. KUHP tidak mengenal tindak pidana perdagangan bayi. KUHP hanya mengatur perdagangan perempuan dan anak laki-laki yang belum cukup umur dimana tujuannya berbeda dengan tujuan perdagangan bayi.

Undang-Undang Pemberantasan Perdagangan Perempuan Dan Anak (RUU PPPA) belum ada pasal yang khusus mengatur perdagangan bayi, oleh sebab itu perlu dikaji kembali dan perlu adanya perbandingan dengan negara lain untuk mencapai hasil yang maksimal.

b. Korporasi dalam KUHP tidak diakui sebagai subjek hukum sehingga hal ini menyulitkan dalam pertanggungjawaban pidana.

c. Walaupun Undang-Undang Perlindungan Anak tidak secara tegas mengatur tentang perdagangan bayi namun secara implisit telah dapat mengakomodir tindak pidana perdagangan bayi, Tetapi Undang-undang Perlindúngan Anak tersebut tidak menjelaskan secara rinci perbuatan-perbuatan apa saja yang sudah dapat dikategorikan sebagai perbuatan tindak pidana perdagangan anak termasuk bayi.

2. Mengenai kebijakan penanggulangan tindak pidana perdagangan bayi dalam hukum pidana dimasa mendatang, baik itu dalam Konsep KUHP 2004 maupun dalam Rancangan

\section{F. SARAN}

Mengingat tujuan dan penyebab yang khas dari perdagangan bayi serta demi perlindungan bayi-bayi Indonesia dari pihak-pihak yang tidak bertanggung jawab maka perlu disempurnakan RUU PPPA atau Konsep KUHP terutama masalah batas usia antara anak dan bayi serta perumusan tindak pidana yang mengkhususkan pada tindak pidana perdagangan bayi sehingga penanggulangan perdagangan bayi memiliki landasan hukum yang kuat. 


\section{DAFTAR PUSTAKA}

Achmad, R.S. Soema di Pradja, Pengertian Serta Sifatnya Melawan Hukum Bagi Terjadinya Tindak Pidana (Dihubungkan Dengan Beberapa Putusan Mahkamah Agung), Armico, Bandung, 1983

Atmasasmita, Romli, Sistem Peradilan Pidana (Criminal Justice System), Bina Cipta, Bandung, 1996

$\begin{array}{lll}\text { Pidana } & \begin{array}{c}\text { Pengantar } \\ \text { Internasional, }\end{array} & \text { Refika } \\ \text { Aditama, Bandung, 2000. } & \end{array}$

Bagong, Suryanto, Pelanggaran Dan Perlindungan Sosial Bagi Anak Rawan, Airlangga University Press, Surabaya, 2003

Bassar, M.Sudradjat, Tindak-Tindak Pidana tertentu Di Dalam Kitab UU Hukum Pidana, Remadja Karya, Bandung, 1986

Black, Henry Campbell, Black's Law Dictionary (Sixth Edition), West Publicing Co., St. Paul, Minnesota, USA

Faisal, Sanapiah, Penelitian Kualitatif Dasa-Dasar dan Aplikasi, YA3, Malang, 1990.

Gosita, Arif, Masalah Perlindungan Anak, Akademika Pressindo, Jakarta, 1985

Hadisuprapto, Paulus, Juvenile Delinquence (Pemahaman Dan Penanggulangannya), Citra Aditya Bakti, Bandung, 1997

Hairiah, Sekilas Gambaran Perdagangan perempuan Dan Anak-Anak Di Kalimantan Barat, dalam Jurnal Perempuan Edisi No.29 Mei 2003

Ham Dalam Praktek Panduan Melawan Perdagangan

Perempuan Dan Anak, Global Alliance Against Traffick in Women (GAATW), Bangkok, diterjemahkan oleh Lembaga Advokasi Buruh Migrant Indonesia, Jakarta, 1999

"Harkrisnowo, Harkristuti, Perdagangan Manusia Dalam RUU Konteks Indonesia Dan Sanksi Pidana Dalam RUU Pemberantasan Perdagangan PerempuanDan Anak, Majalah Forkaphi, No I Mei 2003

Tantangan Dan

Agenda Untuk Hak-Hak Anak (Suatu Usulan Pemikiran), Komisi Hukum Nasional, Jakarta

Irwanto, Fentiny Nugroho, Johanna Debora Imelda, Perdagangan Anak di Indonesia, Kantor Perburuhan Internasional Program Internasional Penghapusan Perburuhan Anak kerjasama dengan Jurusan llamu Kesejahteraan Sosial FISIP - UI, Jakarta, 2001

Joni, Muhammad dan Zulchaina Z. Tanamas, Aspek Hukum Perlindungan Anak Dalam Perspektif Konvensi Hak Anak, PT. Citra Aditya Bakti, Bandung, 1999

Lamintang.P.A.F., Delik-Delik Khusus Tindak Pidana- Tindak Pidana Melanggar Norma-Norma Kesusilaan Dan Norma-Norma Kepatutan, Mandar Maju, 1990 
Muladi, Demokratisasi, Hak Asasi Manusia, dan Reformasi Hukum di Indonesia, Habibie Center, Jakarta, 2002

Muladi dan Barda Nawawi Arief, Teori-Teori dan Kebijakan Pidana, Alumni , Bandung, 1984.

\section{-.---.-, Bunga Rampai Hukum} Pidana, Alumni, Bandung, 1992.

Moeljatno, KUHP Kitab UndangUndang Hukum Pidana, Bumi Aksara, Jakarta, 2003.

Hukum Pidana Indonesia, Bina
Aksara, Jakarta, 1985.
Nawawi Arief, Barda , Bunga Rampai Rampai Kebijakan Hukum Pidana, Citra Aditya Bakti, Bandung, 1996

Hukum dasalah $\begin{array}{r}\text { Penegakan } \\ \text { Kebijakan }\end{array}$
Penanggulangan Kejahatan, Citra
Aditya Bakti, Bandung, 1998

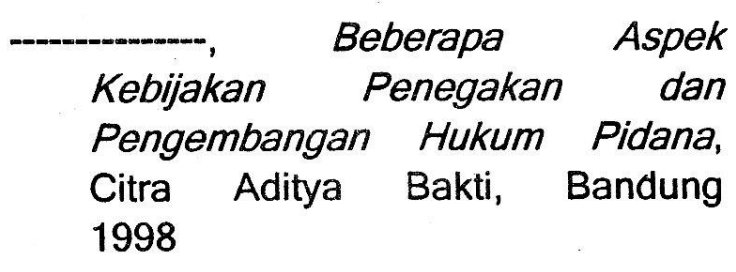

\begin{tabular}{lcc} 
& Kebijakan Legislatif \\
Dalam & \multicolumn{2}{c}{ Penanggulangan } \\
Kejahatan Dengan & Pidana \\
Penjara, Badan Penerbit Undip, \\
Semarang 2000
\end{tabular}

\section{-...-...-..., Kapita Selekta Hukum}

Pidana, Citra Aditya Bakti,

Bandung 2003

Pidana Dalam Perspektif Kajian

Perbandingan, Program Magister llmu Hukum Pascasarjana

UNDIP, 2005

Pemberantasan Child Trafficking Lintas Sektoral, Child Trafficking News, Edisi II/ Januari-Pebruari, 2002

Putra Jaya,Nyoman Serikat, Kapita Selekta Hukum Pidana, Badan Penerbit Universitas Diponegoro, Semarang, 2001

Remelink Jan $\mathrm{Pi}$, Hukum dana Komentar Atas Pasal-Pasal Terpenting Dari Kitb UndangUndang Hukum Pidana Belanda Dan Pidananya Dalam Kitab Undang-Undang Hukum Pidana Indonesia, Gramedia Pustaka Utama, Jakarta, 2003

Sakidjo, Aruan dan Bambang Poenomo, Hukum Pidana Dasar Aturan umum Hukum Pidana Kodifikasi, Ghalia Indonesia, Jakarta, 1990.

Saleh, Roeslan, Segi lain Hukum Pidana, Ghalia Indonesia, Jakarta, 1984.

-..--..-.-.-. Pikiran-Pikiran Tentang Pertanggungan Jawab Pidana, Ghalia Indonesia, Jakarta, 1982

-.--_---.-, Perbuatan Pidana Dan Pertanggungan Jawaban Pidana Dua Pengertian Dasar Dalam Hukum Pidana. Aksara Baru, Jakarta, 1983

Saleh, Wantjik, Tindak Pidana Korupsi, Ghalia Indonesia, Jakarta, 1988

Satrio.J, Hukum Pribadi Bagian / Persoon Alamiah, Citra Aditya Bakti, Bandung, 1999

Sholehuddin, Sistem Sanksi Dalam Hukum Pidana Ide Double Track 
system \& Implementasinya, Raja Graffindo Persada, Jakarta, 2003 Soekanto, Soerjono, Pengantar Penelitian Hukum, UI-Press, Jakarta, 1986

-.-.-., dan Sri Mamuji, Penelitian Hukum Normatif, Raja Grasindo Persada, Jakarta, 1995 Soemitro, Ronny Hanitijo, Metodologi Penelitian Hukum dan Jurimetri, Ghalia Indonesia, Jakarta, 1994.

Dalam Studi Hukum, Remaja Karya, Bandung, 1994.

Normatif, dalam $\begin{gathered}\text { Penelitian } \\ \text { Mukum } \\ \text { Majalah }\end{gathered}$
Masalah-Masalah Hukum No.1/
Tahun 1991

-.-, Teori-Teori Dalam
IImu Hukum, dalam Majalah Masalah-Masalah Hukum No.7I Tahun 1989

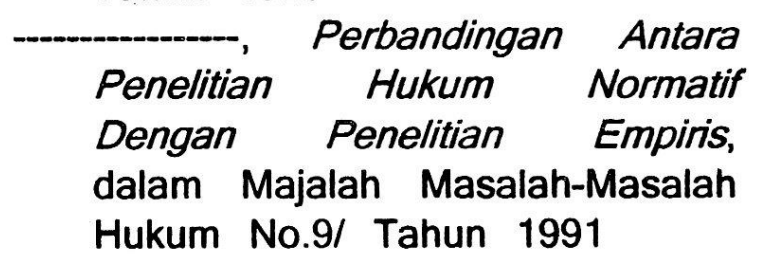

Soemitro, Irma setyowati, Aspek Hukum Perlindungan Anak, Bumi Aksara, Jakarta, 1990.

Soesilo R , Kitab Undang-Undang Hukum Pidana (KUHP) Serta Komentar-Komentamya Lengkap Pasal Demi Pasal, Politeia, Bogor, 1983

Soe'oed, R.Diniati, Penyunting T.O. Ihromi, Bunga Rampai Sosiologi Keluarga, Yayasan Obor Indonesia, Jakarta, 1999.

Sudarto, Hukum dan Hukum Pidana, Alumni, Bandung, 1983
-.-.- Hukum Pidana I, Yayasan Sudarto, Semarang 1990

Kapita Selekta Hukum Pidana, Alumni Bandung, 1981

Hukum Pidana dan Perkembangan Masyarakat.

Kajian Terhadap Pembaharuan Hukum Pidana, Sinar Baru, Bandung 1983

Sughandi,S, KUHP Dan Penjelasannya, Usaha Nasional, Surabaya, 1980.

Sutarto, Suryono, Hukum Acara Pidana I, Yayasan Cendikia Purna Dharma, Semarang, 1987

- Hukum Acara Pidana I, Yayasan Cendikia Purna Dharma, Semarang, 1987

Suyanto, Perdagangan Anak Perempuan Kekerasan Seksual dan Gagasan Kebijakan, Pusat Studi Kependudukan dan Kebijakan Universitas Gajah Mada, Ford Foundation, Yogyakarta, 2002

Tahuleley Sid, Adde Marup WS, Haedar Nashir, Masa Depan Kemanusiaan, LP3 Universitas Muhammadiyah berkerja sama dengan Penerbit Jendela, Yogyakarta, 2003

Wadong, Maulana Hassan, Pengantar Advokasi Dan Hukum Perlindungan Anak, Grasindo, Jakarta, 2000

Wignjosoebroto, Soetandyo, Kebijakan Kriminalisasi Dan Dekriminalisasi Dalam Pembaharuan Hukum Pidana Indonesia (prespektif Sosiologis Dan Kontribusinya Dalam Penyusunan Kebijakan Kriminalisasi Dan Dekriminalisasi), 
Makalah Seminar Nasional

Kriminalisasi Dan Pembaharuan

Hukum Pidana Indonsia,

Yogyakarta, 1983

Wijaya, Samudra, Kebijakan Publik,

Grasindo, Jakarta, 1994

Wahid, Abd, Modus-Modus

Kejahatan Modern, Tarsito, Bandung, 1993

Zaini, Muderis, Adopsi Suatu

Tinjauan dari Tiga Sistem

Hukum, Sinar Grafika, Jakarta, 2002.

\section{Perundang-undangan}

KUHP

Konsep KUHP 2004

Undang-Undang No.4 Tahun 1979

Tentang Kesejahteraan Anak

Undang-undang No. 23 Tahun 2002,

Tentang Perlindungan Anak

RUU Pemberantasan Perdagangan

Perempuan Dan Anak.

SEMA RI No.6 Tahun 1983

Tentang Penyempurnaan SEMA

RI No.2 Tahun 1979. Perihal

Pengangkatan Anak

\section{Majalah-Jumal}

Varia Peradilan No.231, Desember 2004

Jurnal Perempuan No.29 Tahun 2003

Jurnal Forkaphi Vol 1, No 1, 2003

Kompas, 12 September 2003.

Konvensi Hak-hak Anak, United

Nations Children's Fund.

Protokol PBB 